\title{
PERBANDINGAN KADAR BORAKS PADA BAKSO TUSUK SEBELUM DIBAKAR DAN SESUDAH DIBAKAR \\ YANG DIJUAL DI KRAMAT JATI \\ JAKARTA TIMUR
}

\author{
*Masdianto ${ }^{1)}$, Catu Umirestu Nurdiani ${ }^{1)}$, Ahmad Iqbal ${ }^{1)}$ \\ Program Studi Analis Kesehatan, Fakultas Kesehatan, Universitas Mohammad Husni Thamrin \\ Correspondence author: Masdianto, gene234@gmail.com, Jakarta, Indonesia
}

\begin{abstract}
ABSTRAK
Bakso tusuk bakar adalah yang diolah dengan bumbu khusus dan dibakar langsung. Salah satu penyalahgunaan pemakaian boraks yaitu untuk pembuatan bakso. Boraks toksik bersifat (racun) untuk semua sel dan jaringan tubuh, termasuk ginjal, dapat menimbulkan radang pada saluran pencernaan, degenerasi atau pengecilan hati.

Tujuan penelitian ini untuk mengetahui kadar boraks pada bakso tusuk dengan membandingkan kadar boraks sebelum dibakar dan sesudah dibakar. Jumlah sampel dalam penelitian ini 10 bakso tusuk. Uji kualitatif dengan cara uji nyala api dan kertas kurkumin, Uji kuantitatif dengan metode spektrofotometri.

Hasil penelitian didapat sampel positif mengandung boraks, dengan kadar tertinggi sebelum dibakar 1,94 ppm (sampel BF) dan kadar terendah sebelum dibakar 0,54 ppm (sampel BC). Kadar tertinggi sesudah dibakar 1,68 ppm (sampel BF) dan kadar terendah 0,50 ppm (sampel BC). Tidak ada perbedaan kadar boraks pada bakso tusuk sebelum dibakar dan bakso tusuk sesudah dibakar. Proses pembakaran tidak mempengaruhi penurunan kadar boraks pada bakso tusuk.
\end{abstract}

Kata kunci $\quad$ : Boraks, Bakso Tusuk, Sebelum dan Sesudah

\section{ABSTRACT}

Grilled skewers are processed with special seasonings and burned directly. One of the misuse of borax is for the manufacture of meatballs. Toxic borax is toxic (toxic) to all cells and tissues of the body, including the kidneys, can cause inflammation of the gastrointestinal tract, degeneration or shrinking of the liver.

The purpose of this study was to find out the levels of borax in skewers by comparing borax levels before burning and after burning. The number of samples in the study was 10 meatball skewers. Qualitative test by way of flame test and curcumin paper, Quantitative test with spectrophotometric method.

The results of the study found positive samples contained borax, with the highest levels before burning $1.94 \mathrm{ppm}$ (BF sample) and the lowest level before burning $0.54 \mathrm{ppm}$ (BC sample). The highest level after burning was $1.68 \mathrm{ppm}$ (BF sample) and the lowest level was $0.50 \mathrm{ppm}$ (BC sample). There is no difference in borax levels in the skewers before burning meatballs and skewers after burning. The combustion process does not affect the decrease in borax levels in skewers.

Keywords : Borax, Meatball Skewers, Before and After 


\section{PENDAHULUAN}

Keselamatan dan kesehatan masyarakat harus dilindungi dari pangan yang tidak memenuhi syarat keamanan dan dapat membahayakan kesehatan masyarakat. Pemerintah, industri pangan dan konsumen bertanggung jawab terhadap penjaminan pangan yang bermutu dan aman, sesuai dengan tugas dan fungsinya masing-masing (Cahyadi, 2008)

Makanan yang disukai dan berkualitas baik adalah makanan yang memiliki bentuk dan aroma yang menarik, rasa yang enak, warna dan konsistensinya baik serta awet. Untuk mendapatkan makanan yang diinginkan maka sering pada proses pembuatannya dilakukan penambahan "Bahan Tambahan Pangan (BTP)" yang disebut zat aktif kimia (food additive) (Widyaningsih, 2006)

Salah satu keamanan pangan yang masih memerlukan pengawasan yaitu penggunaan Bahan Tambahan Pangan (BTP) untuk berbagai keperluan. Bahan Tambahan Pangan (BTP) juga biasa disebut dengan zat adiktif makanan (food additive) bahan kimia makanan, atau bahan tambahan makanan. Di dalam Peraturan Menteri Kesehatan RI No. 033/Menkes/Per/XI/2012 dijelaskan, bahwa BTP adalah bahan yang biasanya tidak digunakan sebagai makanan dan biasanya merupakan ingredient, khas makanan, punya atau tidak punya nilai gizi, yang dengan sengaja ditambahkan ke dalam makanan untuk maksud teknologi pada pembuatan, pengolahan, penyiapan, perlakuan, pengepakan, pengemasan, penyimpanan atau pengangkutan makanan untuk menghasilkan atau diharapkan menghasilkan suatu komponen atau memengaruhi sifat makanan tersebut (Sucipto, 2015) Sedangkan menurut Food and Agriculture Organization-World Health Organization (FAO-WHO) adalah bahan yang ditambahkan dengan sengaja ke dalam makanan dalam jumlah tertentu, dengan tujuan memperbaiki penampakan, warna, bentuk, cita rasa, tekstur, flavour, dan memperpanjang daya simpan (Effendi, 2012)

BPOM (Badan Pengawas Obat \& Makanan) banyak menemukan kasus-kasus dari temuan hasil penelitian terhadap jajanan pangan anak sekolah. Namun ironisnya, hingga saat ini masih banyak jajanan anak sekolah yang berbahaya dijual di lingkungan sekolah. Jajanan tidak sehat itu mengandung setidaknya satu atau lebih dari zat-zat yang berbahaya, yakni boraks. Bersifat karsinogenik atau memicu kanker. Boraks dan biasa digunakan sebagai pengawet. Pengambilan sampel yang dilakukan BPOM tahun 2011, menemukan setidaknya ada bahan berbahaya yang dilarang digunakan untuk pangan, seperti boraks (BPOM, 2013)

Keamanan makanan merupakan aspek yang sangat penting dalam kehidupan sehari-hari. Dalam prakteknya masih banyak produsen pangan yang menggunakan bahan tambahan yang tidak diizinkan penggunaannya atau berbahaya bagi kesehatan. Penambahan pengawet makanan mempunyai pengaruh yang sangat besar terhadap selera dan daya tarik konsumen. Salah satu bahan untuk mengawetkan seperti boraks dimana bahan kimia ini sangat toksik bagi manusia (Kemenkes RI, 2013).

Boraks bersifat toksik (racun) untuk semua sel dan jaringan tubuh termasuk ginjal, dapat menimbulkan radang pada saluran pencernaan, degenerasi atau pengecilan hati, Odema/pembengkakan pada otak, 
penimbunan cairan pada organ tubuh. Mengkonsumsi makanan berkadar boraks tinggi selama kurun 5-10 tahun dapat meningkatkan resiko kanker hati (Wahab RA, dkk, 2012).

Boraks merupakan bahan kimia yang digunakan sebagai pengawet kayu, antiseptik kayu dan pengontrol kecoa. Boraks sendiri sangat mudah didapatkan dengan harga yang murah sehingga banyak produsen yang menggunakannya sebagai bahan tambahan untuk produk yang dijualnya. Penggunaan boraks dalam pangan perlu diwaspadai baik oleh produsen maupun konsumen. Seseorang yang mengkonsumsi makanan yang mengandung boraks tidak akan langsung mengalami dampak buruk bagi kesehatan, tetapi senyawa tersebut diserap dalam tubuh secara kumulatif. Selain melalui saluran pencernaan, boraks dapat diserap melalui kulit. Dosis yang cukup tinggi dalam tubuh akan menyebabkan munculnya gejala pusing, muntah, dan kram perut. Pada anak kecil dan bayi, bila dosis dalam tubuhnya sebanyak 5 gram atau lebih dapat menyebabkan kematian, sedangkan untuk orang dewasa kematian terjadi pada dosis 10 sampai 20 gram (Asterinai et al, 2006).

Salah satu penyalahgunaan boraks yaitu untuk pembuatan bakso. Bakso atau baso adalah jenis produk pangan olahan yang berasal dari daging sapi, babi, maupun ayam yang dicampur dengan tepung. Bakso banyak dikonsumsi karena penyajiannya yang praktis dan mudah didapatkan di berbagai tempat seperti swalayan, pasar tradisional, dan warung bakso. Bakso dikonsumsi oleh berbagai kalangan masyarakat mulai dari anak-anak hingga orang tua (Cahyadi, 2008)

Bakso juga merupakan makanan yang disukai oleh berbagai kelompok umur dan berbagai golongan masyarakat. Hal inilah yang mendorong para produsen bakso berlomba-lomba untuk menghasilkan bakso yang berkualitas, awet atau tahan lama serta menarik pembeli. Salah satunya dengan memberikan bahan tambahan pangan (Juliana, 2005)

Bakso tusuk bakar merupakan bakso yang diolesi bumbu khusus dan dibakar langsung dan biasanya bumbu oles sebelum dibakar merupakan salah satu yang menentukan enak atau tidaknya bakso bakar. Ketertarikan anak-anak sekolah dasar membeli bakso bakar dikarenakan harganya yang murah dan rasanya yang enak, sehingga anak-anak sekolah dasar menyukai makanan ini (Hardiansyah, 2014)

Hasil penelitian Suci (2009) menyatakan bahwa pada umumnya anak sekolah sering jajan di kantin sekolah, tetapi cenderung memilih makanan yang dijual di luar pagar sekolah. Sekarang ini banyak ditemukan makanan jajanan yang mengandung boraks dan salah satu adalah bakso tusuk. Pedagang berharap dengan penggunaan boraks dapat mengenyalkan bakso dan supaya tahan lebih lama. Bahan kimia seperti boraks sangat membahayakan kesehatan dan umumnya mengakibatkan gangguan pencernaan, diare, kerusakan ginjal dan kesalahan sistem sirkulasi hingga kanker (Sugiyatmi, 2006)

\section{METODE}

Penelitian dilakukan di Laboratorium Kimia Pangan Fakultas Kesehatan Universitas MH. Thamrin, Jakarta Timur, penelitian dilaksanakan 5 Agustus - 23 Agustus 2019. Populasi dari penelitian ini adalah semua bakso tusuk yang dijual di Kramat Jati, Jakarta Timur. Sampel yang diperiksa adalah 
bakso tusuk yang dijual pedagang di Kramat Jati, Jakarta Timur. Sampel dalam penelitian ini bakso tusuk sebelum dibakar dan bakso tusuk sesudah dibakar yang diambil dari pedagang di daerah Kramat jati, Jakarta Timur sebanyak 10 sampel.

\section{HASIL DAN PEMBAHASAN}

Hasil

Hasil dari pembacaan terhadap uji kualitatif yang telah dilakukan dengan menggunakan uji nyala api dan uji kurkumin. Hasil positif dilanjutkan untuk menentukan kadar boraks secara kuantitatif dengan menggunakan metode spektrofotometri.

Tabel 3

Hasil Uji Kualitatif Boraks Pada Bakso Tusuk Sebelum Dibakar dan Sesudah Dibakar Dengan Uji Nyala Api dan Uji Kurkumin di Kramat Jati Jakarta Timur

\begin{tabular}{cccccc}
\hline No. & $\begin{array}{c}\text { Kode } \\
\text { Sampel }\end{array}$ & Uji Nyala & Uji Kurkumin & $\begin{array}{c}\text { Hasil } \\
\text { Sebelum di } \\
\text { Bakar }\end{array}$ & $\begin{array}{c}\text { Hasil } \\
\text { Sesudah di } \\
\text { Bakar }\end{array}$ \\
\hline 1. & BA & Merah & Kuning & -/Negatif & -/Negatif \\
\hline 2. & BB & Merah & Kuning & -/Negatif & -/Negatif \\
\hline 3. & BC & Hijau & $\begin{array}{c}\text { Merah } \\
\text { kecoklatan }\end{array}$ & + +/positif & +/positif \\
\hline 4. & BD & Merah & Kuning & -/Negatif & -/Negatif \\
\hline 5. & BE & Merah & Kuning & -/Negatif & -/Negatif \\
\hline 6. & BF & Hijau & $\begin{array}{c}\text { Merah } \\
\text { kecoklatan }\end{array}$ & + +/positif & + +/positif \\
\hline 7. & BG & Merah & Kuning & -/Negatif & -/Negatif \\
\hline 8. & BH & Hijau & $\begin{array}{c}\text { Merah } \\
\text { kecoklatan }\end{array}$ & +/positif & + +/positif \\
\hline 9. & BI & Merah & Kuning & -/Negatif & -/Negatif \\
\hline 10. & BJ & Hijau & $\begin{array}{c}\text { Merah } \\
\text { kecoklatan }\end{array}$ & +/positif & +/positif \\
\hline
\end{tabular}

Pada tabel 4 didapatkan hasil dari 10 sampel bakso tusuk sebelum dibakar dan sesudah dibakar diperoleh 4 sampel positif mengandung boraks pada kode sampel BC, BF, BH, dan BJ.

Tabel 4

Hasil Uji Kuantitatif Kadar Boraks Pada Bakso Tusuk Sebelum Dibakar dan Sesudah Dibakar di Kramat Jati Jakarta Timur

\begin{tabular}{cccc}
\hline \multirow{2}{*}{ No. } & \multirow{2}{*}{ Kode Sampel } & \multicolumn{2}{c}{ Kadar Boraks (ppm) } \\
\cline { 3 - 4 } & & Sebelum di bakar & Sesudah di bakar \\
\hline 1. & BC & 0,54 & 0,50 \\
\hline 2. & BF & 1,94 & 1,68 \\
\hline 3. & BH & 1,47 & 1,29 \\
\hline 4. & BJ & 1,83 & 1,14 \\
\hline
\end{tabular}

Open Journal System (OIS): journal.thamrin.ac.id 
Dari 4 sampel Bakso Tusuk yang diperiksa Uji Kuantitatif Boraks sebelum dibakar didapatkan hasil kadar tertinggi dengan kode sampel BF dengan kadar boraks 1,94 ppm, dan kadar terendah dengan kode sampel BC dengan kadar boraks 0,54 ppm. Untuk pemeriksaan kuantitatif pada bakso tusuk sesudah dibakar didapatkan hasil kadar boraks tertinggi dengan kode sampel BF dengan kadar 1,68 ppm, dan kadar terendah didapatkan oleh kode sampel BC dengan kadar boraks 0,50 ppm.

Perbandingan kadar rata-rata boraks pada bakso tusuk sebelum dibakar dan bakso tusuk sesudah dibakar yang dijual pada pedagang dilanjutkan dengan uji paired

Tabel 5

Hasil Uji Paired Test Kadar Boraks Pada Bakso Tusuk Sebelum Dibakar dan Sesudah Dibakar

\begin{tabular}{ccc}
\hline Bakso Tusuk & Jumlah & P.value \\
\hline Sebelum dibakar & 8 & 0,128 \\
Sesudah dibakar & & \\
\hline
\end{tabular}

Berdasarkan uji tersebut diperoleh nilai signifikasi 0,128 lebih dari 0,05 maka Ho diterima yang berarti kadar boraks pada bakso tusuk sebelum dibakar dan bakso tusuk sesudah dibakar sama atau tidak ada perbedaan.

\section{Pembahasan}

Penelitian ini dilakukan mengingat boraks tidak boleh digunakan sebagai bahan tambahan pangan sesuai dengan Peraturan Menteri Kesehatan RI No. 33 Tahun 2012 tentang bahan tambahan pangan yang dilarang penggunaannya dalam makanan. Pada penelitian ini untuk uji kualitatif digunakan dengan uji nyala api dan reaksi kertas kurkumin, sedangkan untuk uji kuantitatif digunakan metode spektrofotometri karena mudah, cepat, dan akurat. Sebelum dilakukan uji kuantitatif harus dilakukan uji kualitatif terlebih dahulu.

Pada penetapan kadar boraks dengan uji kuantitatif secara spektrofotometri digunakan panjang gelombang $620 \mathrm{~nm}$. Sampel yang diperiksa adalah bakso tusuk sebelum dibakar dan bakso tusuk sesudah dibakar yang dibeli di Kramat Jati, Jakarta Timur.

Hasil penelitian pada 10 sampel bakso tusuk, didapatkan 4 sampel positif mengandung boraks pada bakso tusuk sebelum dibakar dan bakso tusuk sesudah dibakar. Penelitian yang pernah dilakukan oleh Imelda Horirotul Bariroh (2017), analisis kualitatif dan kuantitatif boraks pada bakso tusuk di Wilayah Kabupaten Bantul Provinsi Daerah Istimewa Yogyakarta, sebanyak 34 sampel bakso tusuk mengandung boraks dengan konsentrasi yang didapatkan berkisar 0,06\%-10,25\% .

Hasil menunjukkan masih ada pembuat bakso tusuk yang menggunakan boraks sebagai pengawet, boraks termasuk salah satu bahan tambahan yang dilarang dimasukkan ke dalam makanan karena 
berbahaya bagi kesehatan. Telah diketahui bahwasannya penggunaan boraks di dalam makanan telah dilarang sejak dahulu, karena boraks bukan bagian dari bahan pengawet untuk makanan melainkan zat kimia untuk bahan industri. Toksisitas boraks untuk tubuh sangatlah berbahaya dan bisa menyebabkan kematian. Penggunaan boraks ini juga terpicu oleh faktor ekonomi dan kurangnya pengetahuan dari masyarakat akan bahayanya boraks bila terdapat dalam makanan yang kita makan dan karena kurangnya pengawasan dari pemerintah atas penjualan boraks yang dapat dibeli oleh masyarakat secara mudah.

Alasan produsen menggunakan boraks sebagai pengawet karena daya awet dan mutu yang dihasilkan menjadi lebih bagus, serta murah harganya tanpa peduli bahaya yang ditimbulkan. Perilaku konsumen juga cendrung membeli makanan berharga murah tanpa memikirkan kualitas. Dengan demikian penggunaan boraks pada makanan di anggap hal biasa. Sulitnya membedakan produk yang dibuat dengan penambahan boraks juga menjadi salah satu faktor pendukung perilaku konsumen tersebut.

Berdasarkan Uji Paired Test tidak ada perbedaan bermakna antara kadar boraks pada bakso tusuk sebelum dibakar dan bakso tusuk sesudah dibakar. Menurut Rumanta, Iryani, dan Ratnaningsih (2016) yang melakukan pengolahan dengan cara merebus dan menggoreng sampel makanan yang mengandung boraks menemukan hasil bahwa perebusan cukup ampuh dalam mengurangi kadar boraks dalam makanan, sementara itu pemanasan dengan cara dibakar hingga matang ternyata tidak mengurangi kadar boraks dalam makanan. Hal ini menunjukan bahwa proses pembakaran tidak mempengaruhi penurunan kadar boraks dalam makanan, bahkan tidak menyebabkan hilangnya boraks melalui proses pembakaran.

Dilihat dari Sifat kimia asam borat antara lain : titik lebur $170,9^{\circ} \mathrm{C}$, titik didih $300^{\circ} \mathrm{C}$, kelarutannya dalam air pada suhu ruang $\left( \pm 27^{\circ} \mathrm{C}\right)$, semakin tinggi suhu yang digunakan untuk melarutkan boraks $\left(100^{\circ} \mathrm{C}\right)$ maka tingkat kelarutannya juga semakin tinggi, kelarutannya dalam air adalah 4-5 gr/100 ml air.

\section{SIMPULAN}

Dari hasil pemeriksaan yang dilakukan di Laboratorium Kimia Pangan Universitas MH.Thamrin terhadap sampel bakso tusuk sebelum dibakar dan bakso tusuk sesudah dibakar yang dijual pada pedagang dengan cara pemeriksaan menggunakan uji kualitatif dan kuantitatif dari 10 sampel yang diperiksa didapatkan hasil :Pada bakso tusuk sebelum dibakar terdapat 4 sampel positif dan 6 sampel negatif dan bakso tusuk sesudah dibakar terdapat 4 sampel positif dan 6 sampel negatif. Pada bakso tusuk sebelum dibakar didapatkan kadar tertinggi pada sampel BF sebesar 1,94 ppm dan kadar boraks terendah pada sampel BC sebesar 0,54 ppm. Sedangkan pada bakso tusuk sesudah dibakar didapatkan Kadar tertinggi pada sampel BF sebesar 1,68 ppm dan kadar boraks terendah pada sampel BC sebesar $0,50 \mathrm{ppm}$. Tidak ada perbedaan yang signifikan antara kadar boraks pada bakso tusuk sebelum dibakar 
dan bakso tusuk sesudah dibakar dimana proses pembakaran tidak mempengaruhi terjadinya penurunan kadar boraks.

\section{UCAPAN TERIMA KASIH}

Penulis mengucapkan terima kasih kepada Kepala Laboratorium Kimia Fakultas Kesehatan Universitas MH Thamrin dan Prodi D III Analis Kesehatan Universitas MH Thamrin berperan serta dalam penelitian ini.

\section{DAFTAR PUSTAKA}

1. Asterina., E., dan Endrinaldi. 2006. Identifikasi dan Penetapan Kadar Boraks Pada Mie Basah Yang Beredar di Beberapa Pasar di Kota Padang. Majalah Kedokteran Andalas No.2. Vol. 32. Fakultas Kedokteran. Universitas Andalas.

2. BPOM. 2002. Informasi Penanganan Bahan Berbahaya : Boraks (Borax). Direktorat Pengawasan Produk dan Bahan Berbahaya, Deputi Bidang Pengawasan Keamanan Pangan dan Bahan Berbahaya. Jakarta : BPOM.

3. BPOM. 2013. Ciri Bakso yang Mengandung Boraks. Jakarta : BPOM

4. Cahyadi, W. 2008. Analisis Dan Aspek Kesehatan Bahan Tambahan Pangan Edisi 2 Cetakan I. Jakarta: Bumi Aksara.

5. Effendi, S. 2012. Teknologi Pengolahan Dan Pengawetan Pangan. Edisi ke-2. Alfabeta. Bandung.Farmakope Indonesia edisi 21972

6. Hardiansyah R. Analisis Preferensi Konsumen Bakso Bakar (Studi Kasus: Kecamatan Medan Tembung, Kota Medan). Anal Prefer Konsum Bakso Bakar (Studi Kasus Kec Medan Tembung, Kota Medan). 2014;

7. Hasanudin (2016) "Analisa Kadar Likopen Pada Tomat Dengan Menggunakan Spektrofotometer Visible, Universitas Diponegoro

8. Juliana, A.M. 2005. Identifikasi Boraks pada Bakso Sapi Bermerk yang Dijual di Pasar Swalayan Kota Semarang. Skripsi. Semarang: Fakultas Kesehatan Masyarakat Universitas Diponegoro Semarang.

9. Kementerian Kesehatan RI. Pedoman Pembinaan Terpadu Makanan Jajanan Anak Sekolahan. Jakarta Kementerian Kesehatan RI. 2013;Obat BP, Makanan RI. Laporan Tahunan 2013.

10. Purnomo H dan Rahadiyan D. 2008. Indonesian Traditional Meatball. International Food Research Journal [internet]. [diunduh 24 Januari 2014]. 15(2): 101-108(2008).

11. R.A.Day.J.R \& A.L.Umderwood, 2002. Analisa Kimia Kuantitatif , Edisi Keenam. Jakarta : Erlangga

12. Saparinto, C. dan Hidayati, D. 2006. Bahan Tambahan Pangan. Yogyakarta: Kanisius 
13. Stefany, A. 2006. Evaluasi Keamanan Pangan Bakso Cilok Ditinjau dari Kandungan Boraksnya Dibeberapa Sekolah Dasar (SD) Di Wilayah Semarang [skripsi]. Semarang.

14. Sucipto, C. D. 2015. Keamanan Pangan. Gosyen Publishing. Yogyakarta.

15. Suherman, Eman, 2004. Kimia Instrumen. ST MIPA. Bogor

16. Suklan, H. 2002. Apa da Mengapa Boraks dalam Makanan. Penyehatan Air dan Sanitasi (PAS) Vol. IV. Nomor 7.

17. Syah, D et al. 2005. Manfaat dan Bahaya Bahan Tambahan Pangan. Impunan Alumni Fakltas Teknologi Pangan IPB. Bandung.

18. Tubagus, I., Citraningtyas, G., dan Fatimawali. 2013. Identifikasi dan Penetapan Kadar Boraks Dalam Bakso Jajanan di Kota Manado. (Online) Jurnal Ilmiah Farmasi - UNSRAT Vol. 2 No. 04. ISSN $2302-2493$.

19. Wahab RA, Suharto G, Margawati A. Pengaruh formalin peroral dosis bertingkat selama 12 minggu terhadap gambaran histopatologis duodenum tikus Wistar. Fakultas Kedokteran; 2012.

20. Widyaningsih, T.D. dan Murtini, E.S. 2006. Alternatif Pengganti Formalin Pada Produk Pangan. Trubus Agrisarana, Surabaya.

21. Winarno, F, G. 1991. Kimia Pangan dan Gizi. Jakarta. PT Gramedia Pustaka Utama, 